\title{
Estrogen Receptor Positive by Immunohistochemistry 1-10 Percent
}

National Cancer Institute

\section{Source}

National Cancer Institute. Estrogen Receptor Positive by Immunohistochemistry 1-10

Percent. NCI Thesaurus. Code C141467.

An immunohistochemical staining finding indicating that 1-10 percent of the cells in a

tissue sample are expressing estrogen receptor. 